\title{
MENTAL TOUGHNESS ON ATHLETES: THE INTERACTION OF THE SPORTS TYPE, GENDER AND AGE
}

\author{
Nas Kazım$^{1} \&$ Temel Veysel ${ }^{1}$ \\ ${ }^{1}$ Karamanoglu Mehmetbey University, Physical Education and Sports High School, Karaman, Turkey
}

\begin{abstract}
The aim of the study was to examine the effect of the physical education and sports high school students' mental toughness to the gender, age and sports type. 95 females and 132 males, totally 227 students (Mage $=21.58 \pm 1.98$ ) students studying at Karamanoglu Mehmetbey University Physical Education and Sports High School during the 2017-2018 academic year voluntarly participated in this study. In order to determine the students' mental toughness to the gender, age and sports type, Sport Mental Toughness Questionnaire developed by Sheard et al. (2009) was used and the SPSS 25.0 program was used for the statistical analysis of the data. Kurtosis and Skewmess values were observed in order to test whether the subscales of both scales showed normal distribution and at the end of which all subscales of mental toughness scale showed normal distribution. According to this, Manova and ANOVA analysis to determine the main was performed. As a result; it has been identified that students are mentally powerful and tough for mental toughness. Mental toughness levels have no interaction among doing sports, age and gender.
\end{abstract}

Keywords: Mental Toughness, Sports, Student.

\section{INTRODUCTION}

Variations in physical skills and abilities can affect competition results. However, in many competitions, the athletes' winning or losing depends on their performance on the day of the competition. In case athletes are physically equal, the successful ones are usually those who are at higher levels of mental skills (Weinberg and Gould, 2015). Human is a bio-psycho-social creature. Human is all with cognitive, emotional, physical and social aspects. The sporting abilities of the people can be brought to a sufficient level by the coordination of these essential elements together with the planning and implementation of the required work (Erdoğan ve Kocaekşi, 2015). For this reason, it can be said that psychological and mental elements are factors determining the difference among athletes who have the same level of physiological, motoric, technical and tactical characteristics. During the season, the athlete's mental performance can play an effective role in her and his team's success in the field. Especially during the periods when the teams play very often, the need for athletes' psychological well-being is increasing more and more due to the decline in performance on the field. Athletes are physically and psychologically adversely affected by high-level workouts, displacement trips and intense match programs and therefore it is seen that their performance is reduced. In recent years, things that sports psychologists are doing to improve performance have become increasingly important. Some coaches, trainers and athletes did 
not believe in sport psychology and so were behind in this respect (Altintas and Akalan, 2008). One of the most commonly used but least understood topics in sport psychology is mental toughness (Graham, Hanton and Connaughton, 2002). In the field writing, numerous concepts related to the development of personality, mental toughness and performance have been gained (Gibson, 1998; Goldberg, 1998). According to Loehr (1982), durable athletes from the mental side have various behaviors that make them emotionally comfortable, calm and strong. There are two skills developed in this direction. First; the ability to use energy efficiently in a crisis and difficult situation, and the other is the ability to think strongly about problems, pressures, mistakes, and correct behavior in the formation of competition. However, mental endurance can be defined as both a personal character (Kroll, 1967) and a mental state (Gibson, 1998). For example, according to Cattell (1957), mental toughness emerges in realistic, independent, timid behavior and emerges as a hard, practical, mature and realistic behavioral dimension. Effectively, Gibson (1998) argues that mental stability is related to self-efficacy and internal control focus. In addition, one of the important factors for the performance of the athletes is personality.

The aim of this study was to examine the mental toughness of students studying at Physical Education and Sports High School and to investigate the effect of the age, sport type and gender variables.

\section{MATERIALS AND METHODS}

\section{Research Model}

This research is a descriptive study aimed at examining the predictability of the effects of students' mental toughness levels to the gender, age and sports type in the school of Physical Education and Sports. Descriptive method is a research method aiming to define existing event / phenomenon without intervention of researcher (Karasar, 1995). Descriptive studies aim to define typical characteristics of a particular group and to make conclusions about how people in a particular group will behave in response to certain situations (Borg- Gall, 1989).

\section{Research Group}

The research group consists of 95 female and 132 male students, totally of 227 students (age average $=21,58 \pm 1,98)$ studying at 1 st, 2 nd,3rd and 4th classes in a university during 2017-2018 education period. The research scale was voluntarily applied on students face to face by being interviewed where they learned.

\section{Data Collection Tools}

The data collection tools required to achieve the research objectives are given below: 


\section{1- Personal Information Form}

To collect information about the personal characteristics of the participants and to establish the independent variables of the research, an information form consisting of 4 variables (Gender, Age, Doing Sports Date and Sports Type) was prepared by the researcher

\section{2- Sport Mental Toughness Questionnaire-SMTQ}

In order to determine the level of mental toughness in the sports, Sport Mental Toughness Questionnaire - SMTQ-14 developed by Sheard et al. consists of 14 items. In addition to the general mental toughness, the scale consists of three sub-dimensions (Confidence, Control and Constancy) with the 4-point Likert type ( 1 = False; 4 = Fully True). The Cronbach Alpha values for the subscales of the original scale were 0.81 for the confidence subscale; 0.74 for constancy sub-dimension; The control subscale was 0.71 (Sheard et al., 2009).

As a result of the analyzes conducted on 509 athletes participating in the inventory with a mean age of 20, the fitness index values; Good compliance index as $(\mathrm{GCI})=0.95$, Corrected goodness of fit index as $(\mathrm{CGFI})=0.93$, The mean error square root mean as (MESR) is 0.05 , The residual compliance index as $(\mathrm{RCI})=0.05$, The comparative compliance index $(\mathrm{CCI})=0.92$, The incremental compliance index (ICI) 0.93 were found (Sheard et al., 2009).

The internal consistency (Cronbach Alpha) reliability coefficients of this study were found as .79 for total mental toughness, .78 for confidence in mental toughness subscales, .74 for constancy and .72 for control.

\section{Collection of Data}

First, the available information on the purpose of the research was given in a systematic way by searching the literature. Thus, a theoretical framework has been established. Second, " Sport Mental Toughness Questionnaire-SMTQ " developed by Sheard et al. (2009) and information form to gather the participants' personal information were used.

\section{Analysis of The Data}

During the analysis and evaluation of the data; the data was analyzed by using the Spss 25.0 for windows package program. The percentage and frequency were used to determine the distributions of personal information of the participants. Kurtosis and Skewness values were observed in order to test whether the subscales of both scales showed normal distribution. At the end of which all subscales of mental toughness scale showed normal distribution. Accordingly, Manova and ANOVA analysis to identify the main differences was performed.

\section{Personal Characteristics of the Research Group}

The data and comments on the demographic characteristics of the students participating in the survey are given below. 
Table 1. Demographic Characteristics of the Sample Group Participated In the Survey

\begin{tabular}{|cc|cc|}
\hline & & $\mathbf{n}$ & $\mathbf{\%}$ \\
\hline \multirow{2}{*}{ Gender } & Female & 95 & 41,9 \\
\cline { 2 - 4 } Age & Male & 132 & 58,1 \\
\cline { 2 - 4 } & $18-20$ Age & 113 & 49,8 \\
\cline { 2 - 4 } Sports Type & $21-23$ Age & 114 & 50,2 \\
\cline { 2 - 4 } & Individual & 112 & 49,3 \\
\hline \multirow{2}{*}{ Sports Duration } & Team & 115 & 50,7 \\
\cline { 2 - 4 } & 2 years and & 31 & 13,7 \\
\cline { 2 - 4 } & 3-5 years & 52 & 22,9 \\
\cline { 2 - 4 } & 6-8 years & 92 & 40,5 \\
\hline
\end{tabular}

According to table 1, 41.9\% of participants were female participants while $58.1 \%$ were male participants. According to the age variable, $49.8 \%$ is $18-20$ years old while $50.2 \%$ is $21-23$ years old. According to the type of sport type, $49.3 \%$ are doing sports in individual teams while $50.7 \%$ are doing sports in team sports. According to the variable duration of sports, $13.7 \%$ of them are doing sports for 2 years and below, $22.9 \%$ from 3 years to 5 years, $40.5 \%$ from 6 years to 8 years and $22.9 \%$ from 9 years and over.

Table 2. Results of The Participants' Mental Toughness on Total Score and Sub-Dimension Levels

\begin{tabular}{|c|c|c|c|c|c|c|}
\hline \multicolumn{2}{|c|}{} & $\mathbf{n}$ & $\bar{X}$ & Ss & Min & Max \\
\hline \multirow{4}{*}{ Mental Toughness } & Total Mental Toughness & 227 & 40,59 & 5,48 & 16,00 & 53,00 \\
\cline { 2 - 7 } & Confidence & 227 & 17,99 & 3,19 & 6,00 & 24,00 \\
\cline { 2 - 7 } & Contancy & 227 & 10,93 & 1,97 & 4,00 & 16,00 \\
\cline { 2 - 7 } & Control & 227 & 11,66 & 2,39 & 4,00 & 16,00 \\
\hline
\end{tabular}

In Table 2, point averages of total points and sub-dimensions of the participants were examined. As a result of this review; it can be said that the participants' level mental tougness was high with 40.6, high confidence level with 17.9 from mental toughness subscales, higher constancy level than middle level with 10.93 and high control level with 11.66. 
Table 3. Level of participants' mental toughness MANOVA Table

\begin{tabular}{|c|c|c|c|c|c|}
\hline & & $\mathbf{F}$ & Hipotez df & Mistake df & Sig. \\
\hline \multirow{4}{*}{ Age } & Pillai's Trace & $3,04 \mathrm{~b}$ & 3,00 & 548,00 & 03 \\
\hline & Wilks' Lambda & $3,04 \mathrm{~b}$ & 3,00 & 548,00 & 03 \\
\hline & Hotelling's Trace & $3,04 \mathrm{~b}$ & 3,00 & 548,00 &, 03 \\
\hline & Roy's Largest Root & $3,04 \mathrm{~b}$ & 3,00 & 548,00 & 03 \\
\hline \multirow{4}{*}{ Sports Type } & Pillai's Trace &, $43 b$ & 3,00 & 548,00 & ,73 \\
\hline & Wilks' Lambda & ,43b & 3,00 & 548,00 & ,73 \\
\hline & Hotelling's Trace & ,43b & 3,00 & 548,00 & ,73 \\
\hline & Roy's Largest Root & $43 b$ & 3,00 & 548,00 & ,73 \\
\hline \multirow{4}{*}{ Gender } & Pillai's Trace & $7,42 b$ & 3,00 & 548,00 &, 00 \\
\hline & Wilks' Lambda & $7,42 b$ & 3,00 & 548,00 &, 00 \\
\hline & Hotelling's Trace & $7,42 b$ & 3,00 & 548,00 &, 00 \\
\hline & Roy's Largest Root & $7,42 b$ & 3,00 & 548,00 &, 00 \\
\hline \multirow{4}{*}{ Age*Sports Type*Gender } & Pillai's Trace & $1,21 \mathrm{~b}$ & 3,00 & 548,00 & ,30 \\
\hline & Wilks' Lambda & $1,21 b$ & 3,00 & 548,00 & ,30 \\
\hline & Hotelling's Trace & $1,21 \mathrm{~b}$ & 3,00 & 548,00 & ,30 \\
\hline & Roy's Largest Root & $1,21 \mathrm{~b}$ & 3,00 & 548,00 &, 30 \\
\hline
\end{tabular}

There was no difference among the participants' doing sports, age and gender type variables according to $(\mathrm{F}(3,548)=1.21, \mathrm{p}<.05$.

Table 4. Participants' Mental Toughness level ANOVA Table

\begin{tabular}{|c|c|c|c|c|c|}
\hline \multicolumn{2}{|c|}{ Dependent Variables } & df & Mean Square & $\mathbf{F}$ & Sig. \\
\hline \multirow{4}{*}{ Age } & Total Mental Toughness & 1 & 16,740 &, 552 &, 458 \\
\hline & Confidence & 1 & ,405 & ,040 & 841 \\
\hline & Contancy & 1 & 1,902 & ,493 & ,483 \\
\hline & Control & 1 & 4,308 & ,759 & ,384 \\
\hline \multirow{4}{*}{ Sports Type } & Total Mental Toughness & 1 & 25,145 & ,829 & ,363 \\
\hline & Confidence & 1 &, 369 & ,037 &, 848 \\
\hline & Contancy & 1 & 16,621 & 4,311 & ,039* \\
\hline & Control & 1 & 2,386 &, 421 &, 517 \\
\hline \multirow{4}{*}{ Gender } & Total Mental Toughness & 1 & 18,260 & ,602 &, 439 \\
\hline & Confidence & 1 & 59,752 & 5,935 &, $016^{*}$ \\
\hline & Contancy & 1 &, 453 &, 118 &, 732 \\
\hline & Control & 1 & 7,747 & 1,366 & ,244 \\
\hline \multirow{4}{*}{ Total } & Total Mental Toughness & 227 & & & \\
\hline & Confidence & 227 & & & \\
\hline & Contancy & 227 & & & \\
\hline & Control & 227 & & & \\
\hline
\end{tabular}

The main effects were examined as there was no interaction among the independent variables. According to ANOVA table, there was a statistically significant difference in constancy dimension from mental toughness sub-dimensions according to sport type variable of individual effects $(\mathrm{p}<.05)$. 


\section{DISCUSSION}

Human is a biological entity with its own cultural, mental and psychological structure (Ridley, 2010). For this reason, situations in which an athlete has mental and emotional involvement are directly related to the performance of the athlete. Today, performance in sport is defined as the physiological, biomechanical and psychological efficiency that the athlete shows during the competition. This is due to the fact that both the psychological and physiological capacities of the athlete in order to achieve high and productive performance are improved and appropriately raised to a certain level (Konter, 2003).

When the findings of the study were examined, it was concluded that the levels of mental toughness level of physical education and sports high school students were higher at the level of confidence and control dimension, and the contancy dimension was above the mid-level. According to the study done by Yardımc1 et al. (2017), it can be concluded that the American football athletes' mental toughness in sports is above with average of 30.03 and the result supports the findings of this study.

The mental toughness level of participants did not have interaction between doing sports, age and gender type variables $(\mathrm{F}(3,548)=1.21, \mathrm{p}<.05$. However, when the main effects were examined, it was understood that the students who played in individual sports had higher levels of contancy from the mental toughness sub-dimensions than the students who played in team sports. Although there is no intraction between doing sports and mental toughness, the study researched by Temel (2017) was found that there was a interaction between doing sports and gender.

According to the gender variable, the level of confidence from the mental toughness subdimensions was the result of men feeling more trust than women. In a study of the sample of Pakistani tennis athletes (2014) in the literature, male athletes have a higher arithmetic average in terms of ZD average scores than female athletes. According to a similar study done by Yazıc1 (2016), as a result of statistical differences, female basketball players had a higher average score than male basketball players. So it is seen that our research does not coincide with the findings of research work done by Yazic1 (2016). And also, it can be said that the findings of 677 athletes by Nicholls et al. (2009) did not support the findings that we obtained.

\section{CONCLUSION AND RECOMMENDATIONS}

As a result; physical education and sports college students who participated in the study were found to be about being strong and durable level from the mental side. Mental toughness levels do not have an interaction among doing sports, age and gender.

More work on this area should be done to examine the relationship between variables. This is because the relevant field has made it difficult to interpret the findings that we have lacked empirical studies in the literature. 


\section{REFERENCES}

Altıntaş, A. ve Akalan, C. (2008). Zihinsel antrenman ve yüksek performans. SPORMETRE Beden Eğitimi ve Spor Bilimleri Dergisi, 1,39-43.

Borg, W.R. \& Gall, M. (1989). Educational research: An introduction. New York: Longmen, p.939.

Cattell, R.B. (1957). Personality and motivation structure and measurement. New York: Harcort, Brace and World.

Erdoğan, N. ve Kocaekşi, S. (2015). Elit sporcuların sahip olması gereken psikolojik özellikler. Türkiye Klinikleri Journal of Sport Science, 7(2), 57-64.

Gibson, A. (1998). Mental Toughness. New York: Vantage Press.

Goldberg, A. S. (1998). Sports slump busting: 10 steps mental toughness and peak performance. Champaign, IL: Human Kinetics.

Graham, J., Hanton, S. and Connaughton, D. (2002). What is this thing called mental toughness? An investigation of elite sport performers. Journal Applied Sport Psychology, 205-218.

Karasar, N. (1995). Bilimsel araştırma yöntemi. Ankara: 3A Araştırma Eğitim Danışmanlık, 292.

Konter, E.(2003). Spor Psikolojisi Uygulamalarında Yanılgılar ve Gerçekler. s. 31-37, 1. Basım, Dokuz Eylül Yayınları, Ankara.

Kroll, W. (1967). Sixteen personality factor profiles of collegiate wrestlers. Research Quarterly, 4957.

Loehr, J. E. (1982). Athletic excellence: Mental toughness training for sport. New York: Plume.

Nicholls, A. R., Polman, C. J., Levy, A. R. and Backhouse, S. H. (2009). Mental toughness in sport: achievement level, gender, age, experience and sport type differences. Personality and Individual Differences, 47,73-75.

Ridley, M.G. (2010). Bir türün yirmi üç bölümlük otobiyografisi. (Çeviri: Mehmet Doğan, Nivart Taşç1). İstanbul: Boğaziçi Üniversitesi Yayınları.

Sheard, M., Golby. J., Van Wersch A. (2009). Progress towards construct validation of the Sports Mental Toughness Questionnaire (SMTQ). European Journal of Psychological Assessment, 25, 186-193.

Temel, V.(2017). Evaluation Of High School Students' Sportıng Situations According To Some Variables. The Journal of International Anatolia Sport Science, Volume: Apr. Issue:2.

Weinberg, R. S. and Gould, D. (2015). Introduction to psychological skills training. R. S. Weinberg, \& D. Gould içinde, Foundations of Sport and Exercise Psychology (s. 247-271). Champaign: Human Kinetics.

Yardımcı, A., Sadık, R., Kardaş, N.T. (2017). Amerikan Futbolu Sporcularının Yalnızlık Düzeyleri ve Sporda Mental Dayanıklılık Düzeyleri Arasındaki İlişki. Spor Bilimleri Araştırmaları Dergisi, 2(2), 79-90. DOI: $10.25307 /$ jssr.337838

Yazıcı, A. (2016). Profesyonel basketbol oyuncularında zihinsel dayanıklılık ve duygusal zekânın çeşitli değişkenler açısından incelenmesi. Yayımlanmamış Yüksek Lisans Tezi, Gazi Üniversitesi, Sağlık Bilimler Enstitüsü, Ankara.

Correspondence for author 